\title{
PROJECT-BASED LEARNING IN FINANCIALS ADVICE
}

\author{
Jordi Capó Vicedo ${ }^{1}$, Antonio Benito ${ }^{1}$, Sergi Montava ${ }^{2}$, Raquel Sanchis ${ }^{3}$ \\ ${ }^{1}$ Departamento de Economía y Ciencias Sociales, Escuela Politécnica Superior de Alcoy. \\ Universitat Politècnica de València (SPAIN) \\ ${ }^{2}$ Departamento de Ingeniería Mecánica y de Materiales, Escuela Politécnica Superior de \\ Alcoy. Universitat Politècnica de València (SPAIN) \\ ${ }^{3}$ Departamento de Organización de Empresas, Escuela Politécnica Superior de Alcoy. \\ Universitat Politècnica de València (SPAIN)
}

\begin{abstract}
The efficient use of the economic resources of companies, both large enterprises and SMEs, as well as the different means to obtain these resources, are critical aspects. For this reason, the new generation of students of degrees such as Business Administration and Management should know in depth the different types of banking entities, the main asset and liability operations of banking entities and the existing risk, as well as the main challenges of the banking sector for the following years. In the same way, a profound comprehension about the stock market and the simulation models to analyse different financial situations are aspects highly valued by companies.

Based on this, learning requirements arise to seek active methodologies that allow students to acquire the knowledge and key competencies that companies currently require. Among these methodologies, we would like to highlight the Project-based Learning (PBL) through which the teaching-learning process is carried out through the development of a project that tries to give an answer to a real problem. Through PBL, students develop a high degree of autonomy and responsibility, since they are responsible for planning, structuring the work and preparing the project to solve a specific problem or situation. The lecturers' work in this methodology is to guide and support students throughout all the process of project development.

Therefore, this article defines a PBL model to satisfy the current needs of the market in terms of financials advice. The PBL model involves two subjects: (i) Banking and Stock Market and (ii) Advanced financial simulation techniques taught in the Degree of Business Administration and Management in the Campus of Alcoy of Universitat Politècnica de València (Spain). The PBL model has been defined collaboratively to be performed on both subjects during one academic year. This PBL model provides students with the necessary skills and abilities to perform financial advisory tasks in the today's business context.
\end{abstract}

Keywords: Project-Based Learning, Financials Advice, Active Methodology, Business Administration and Management.

\section{INTRODUCTION}

The efficient use of the economic resources of companies, both large enterprises and SMEs, as well as the different means to obtain these resources, are critical aspects. For this reason, the new generation of students of degrees such as Business Administration and Management should know in depth the different types of banking entities, the main asset and liability operations of banking entities and the existing risk, as well as the main challenges of the banking sector for the following years. In the same way, a profound comprehension about the stock market and the simulation models to analyse different financial situations are aspects highly valued by companies.

Based on this, learning requirements arise to seek active methodologies that allow students to acquire the knowledge and key competencies that companies currently require. Among these methodologies, we would like to highlight the Project-based Learning (PBL) through which the teaching-learning process is carried out through the development of a project that tries to give an answer to a real problem. Through PBL, students develop a high degree of autonomy and responsibility, since they are responsible for planning, structuring the work and preparing the project to solve a specific problem or situation. The lecturers' work in this methodology is to guide and support students throughout all the process of project development. 
Therefore, this article defines a PBL model to satisfy the current needs of the market in terms of financials advice. The PBL model involves two subjects: (i) Banking and Stock Market and (ii) Advanced Financial Simulation Techniques taught in the Degree of Business Administration and Management in the Campus of Alcoy of Universitat Politècnica de València (Spain). The PBL model has been defined collaboratively to be performed on both subjects during one academic year. This PBL model provides students with the necessary skills and abilities to perform financial advisory tasks in the today's business context.

The paper is structured as follows. Section 2 describes what the PBL methodology consists of. Section 3 illustrates the innovation context in which this PBL model has been defined. Section 4 explains the PBL model proposed and implemented, and the main preliminary results obtained. Finally, section 5 shows the main conclusions and further work lines.

\section{THE ACTIVE METHODOLOGY: PROJECT BASED LEARNING (PBL)}

Project-based learning (PBL) is a constructivist pedagogical approach that aims at bringing about deep learning by allowing lecturers to use an inquiry-based approach to engage with issues and questions that are rich, real and relevant to the topic being studied [1]. Based on this, other authors such as [2] define PBL as a methodology that uses projects as systematic teaching methodology and involves students in learning competences and skills through research assignment, authentic question, and well-designed product. The projects that are presented to students are based on challenging questions and encourage students to play a central role in design, problem-solving, and decision-making processes. In this way, PBL allows students to work with quite autonomy.

The PBL methodology consists of a set of stages sequenced as follows: the first involves the formulation of the expected learning objectives, followed by understanding the concept of the teaching materials, and the competences and skills training. Once that these stages are performed, the project-oriented activities are carried out. Firstly, the project has to be designed carefully, defining the project theme and developing the project proposal. This set of tasks is followed by the execution of the project tasks and the presentation of the project report [3].

In the PBL methodology, the problem presented to students to be solved is frequently a real-world problem characterised by complex aspects that need deep investigation. Moreover, collaboration and teamwork are encouraged through the PBL methodology. In this case, the role of the lecturer is to guide, advise and encourage students to find out responses for the problems proposed. In this sense, the involvement of the lecturer will depend on the maturity level of students' skills. Based on the study performed by [2], Table 1 shows a non-exhaustive list of the main advantages and weaknesses of the PBL methodology.

Table 1. Advantages and disadvantages of the PBL methodology (based on [2]).

\begin{tabular}{|c|c|}
\hline Advantages & Disadvantages \\
\hline $\begin{array}{l}\text { - PBL enhances the motivation of students. } \\
\text { - PBL improves students' academic performance. } \\
\text { - PBL encourages cooperation and collaboration among } \\
\text { students. } \\
\text { - PBL enhances the effective communication and problem- } \\
\text { solving abilities of students. } \\
\text { - PBL is considered as a more enjoyable methodology } \\
\text { than traditional methodologies. } \\
\text { - PBL also allows students to improve their resources and } \\
\text { time management skills. } \\
\text { - PBL makes students more creative and increases their } \\
\text { attitudes toward learning. } \\
\text { - As the PBL encourages teamwork, students share risks, } \\
\text { and they are subject to less anxiety. }\end{array}$ & $\begin{array}{l}\text { - The implementation of a PBL methodology and the } \\
\text { development of the project by students is very time } \\
\text { consuming what will have a negative impact to teach } \\
\text { the necessary contents to be applied in the solving } \\
\text { process. } \\
\text { - Many lecturers are reluctant to change from } \\
\text { traditional educational methodologies to more active } \\
\text { ones such as PBL. } \\
\text { - PBL is an appropriate approach for small classes } \\
\text { (with a limited number of students) but this } \\
\text { methodology is very complex to manage when } \\
\text { classes are larger [2]. } \\
\text { - When the project to be solved by each group of } \\
\text { students is different, it is feared that students cannot } \\
\text { go in depth in the project theme [4]. }\end{array}$ \\
\hline
\end{tabular}

There are many advantages to implement the PBL methodology, however lecturers should also have in mind the problems that could arise during the proposal and an implementation of this methodology. For this reason, it should be studied carefully which subjects are likely to implement PBL and how different subjects can coordinate the implementation of a common project. 


\section{DESCRIPTION OF THE INNOVATION CONTEXT: EDUCATIONAL INNOVATION AND IMPROVEMENT PROJECT}

The PBL model in financial advice has been designed within the framework of an Educational Innovation and Improvement Project (EIIP) that currently is being implemented in Escuela Politécnica Superior de Alcoy that belongs to Universitat Politècnica de València (UPV). In the Campus of Alcoy, there are the following 5 Degrees that participate in this EIIP: (i) Industrial Design and Product Development Engineering; ( $\mathrm{i}$ i) Computer Engineering; ( $\mathrm{i} \mathrm{i}$ i) Business Administration and Management; ( $\mathrm{v}$ ) Mechanical Engineering; and (vi) Chemical Engineering.

The main aim of this project is to include PBL that covers transversally different subjects. The project is mainly addressed to subjects to the last two courses. The reason to define only PBL activities in these courses is because in the first and second year of the different degrees, students are not as mature as in the last course to face up to real problems. Moreover, they need the prior acquisition of basic competences (taught in 1st and 2nd courses), to later be able to solve real problems as projects (PBL models). As aforementioned, students will need different knowledge, competences and skills in each of the phases of the project (PBL model) to be able to solve it successfully. This project has 24 months duration. The activities performed in the first year (Course: 2019-2020) were focused on: (i) identifying the potential subjects to participate in this piloting activity; (ii) analysing the synergies and complementarities among the different subjects and (ii) defining the different PBL model per subjects. This year (academic course: 2020-2021), the activities are focused on: (i) implementing each of the PBL models defined, trying to avoid the problems due to the COVID-19 outbreak and (ii) evaluating the results obtained through different assessment mechanism such as surveys, focus groups, among others.

Table 2 offers an overview of the number of PBL models that are being implemented in the Campus of Alcoy in each of the degrees, as well as the number of subjects, students and lecturers involved in the activities related to this active methodology.

Table 2. Overview of the PBL models defined within the EIIP in the Campus of Alcoy - UPV.

\begin{tabular}{|c|c|c|c|c|c|c|}
\hline Degree & PBL Model & $\begin{array}{c}\text { No. } \\
\text { subjects } \\
\text { involved }\end{array}$ & Cour-se & $\begin{array}{c}\text { No. } \\
\text { lecturers } \\
\text { involved } \\
\end{array}$ & $\begin{array}{l}\text { No. } \\
\text { students } \\
\text { involved }\end{array}$ & Ref. \\
\hline $\begin{array}{l}\text { Industrial Design } \\
\text { and Product } \\
\text { Development } \\
\text { Engineering } \\
\end{array}$ & Product Design Project & $\begin{array}{l}3 \\
5 \\
1\end{array}$ & $\begin{array}{l}2^{\text {nd }} \\
3^{\text {rd }} \\
4^{\text {th }}\end{array}$ & 9 & 160 & \\
\hline \multirow{3}{*}{$\begin{array}{l}\text { Computer } \\
\text { Engineering }\end{array}$} & $\begin{array}{l}\text { Programming and data } \\
\text { structures and algorithms project }\end{array}$ & $\begin{array}{l}1 \\
1\end{array}$ & $\begin{array}{l}1^{\text {st }} \\
2^{\text {nd }}\end{array}$ & 3 & 94 & [5] \\
\hline & $\begin{array}{l}\text { Software Engineering project in } \\
\text { business contexts }\end{array}$ & $\begin{array}{l}3 \\
1 \\
\end{array}$ & $\begin{array}{l}3^{\text {rd }} \\
4^{\text {th }} \\
\end{array}$ & 4 & 69 & [6] \\
\hline & Videogame Project & 2 & $4^{\text {th }}$ & 2 & 18 & [5] \\
\hline $\begin{array}{l}\text { Business } \\
\text { Administration and } \\
\text { Management }\end{array}$ & Financials Advice Project & 2 & $4^{\text {th }}$ & 2 & 7 & \\
\hline \multirow{4}{*}{$\begin{array}{l}\text { Mechanical } \\
\text { Engineering }\end{array}$} & Project Engineering Model & $\begin{array}{l}2 \\
3\end{array}$ & $\begin{array}{l}3^{\text {rd }} \\
4^{\text {th }} \\
\end{array}$ & 4 & 129 & [7-8] \\
\hline & $\begin{array}{l}\text { Vehicle Design and Engineering } \\
\text { Project }\end{array}$ & $\begin{array}{l}1 \\
3 \\
\end{array}$ & $\begin{array}{l}3^{\text {rd }} \\
4^{\text {th }} \\
\end{array}$ & 4 & 29 & [9] \\
\hline & $\begin{array}{l}\text { Design and calculation of a } \\
\text { pressure tank with Solid Works } \\
\text { with the use of composite } \\
\text { materials project }\end{array}$ & 3 & $4^{\text {th }}$ & 3 & 19 & [10] \\
\hline & $\begin{array}{l}\text { Design and Manufacture of } \\
\text { Machines and Prototypes } \\
\text { Project }\end{array}$ & $\begin{array}{l}1 \\
2\end{array}$ & $\begin{array}{l}3^{\text {rd }} \\
4^{\text {th }}\end{array}$ & 4 & 125 & \\
\hline $\begin{array}{l}\text { Chemical } \\
\text { Engineering }\end{array}$ & $\begin{array}{l}\text { Design of an adsorption column } \\
\text { for the elimination of colorants in } \\
\text { wastewater in the textile industry } \\
\text { project }\end{array}$ & $\begin{array}{l}3 \\
4 \\
8 \\
6\end{array}$ & $\begin{array}{l}1^{\text {st }} \\
2^{\text {nd }} \\
3^{\text {dd }} \\
4^{\text {th }}\end{array}$ & 16 & 66 & [11-13] \\
\hline Total & 10 & 55 & & 51 & 716 & \\
\hline
\end{tabular}


There are 10 projects that are being developed. These PBL models involve more than 50 lecturers and subjects, and more than 700 students are benefiting from this methodology. Although only subjects from the last courses were initially planned to participate in the EIIP, at the end, subjects from all the courses (depending on the PBL model) participate what enriches the continuity of active learning throughout the entire grade. More information about the structure of each PBL model may be found in [14].

\section{FINANCIALS ADVICE PBL MODEL}

\subsection{Definition of the PBL activities}

The subjects that are part of the PBL model are "Advanced Techniques for Financial Simulation " and "Banking and stock market", both of which are part of the consulting and finance itinerary corresponding to the $4^{\text {th }}$ year of the Business Administration and Management degree. "Banking and Stock Market" is taught in the first semester while "Advanced Techniques for Financial Simulation" is taught in the second one.

These are elective courses through which students will deepen their knowledge of the financial system and financial markets, as well as the financial analysis of companies.

Due to their optional nature, these are usually subjects with a smaller number of students than the compulsory subjects, which allows the use of different learning methodologies in which lecturers can supervise the groups' work periodically to monitor progress and help them resolve any doubt and/or problem that may arise. In fact, during the 2020/21 academic year, there were 7 students enrolled in both subjects.

It is worth mentioning that in this methodology (PBL model), the method of work is more important than the object of the project. The ultimate goal for students is to be able to analyse the problem to be studied, propose and apply the solution and evaluate the results. In this way, the final product of the project is materialized in a tangible output and a written report.

The project is based on selecting a company that is within the IBEX-35 index ${ }^{1}$ and the performance of different analyses on it. To do this, first of all, different investment alternatives will be proposed based on financial assets issued by the company in order to study its financial situation and analyse different scenarios that affect its business model. Subsequently, the company's financial statements will be analysed in order to complete the previous analysis and be able to draw conclusions about the economic and financial situation of the company and then a number of possible scenarios will be proposed.

Specifically, the project consists of 3 main activities:

- Activity 1 will be carried out within the subject "Banking and Stock Exchange". In this activity 3 investments in financial assets of the same issues will be analysed, in fixed income, variable income, and in derivative products, making, at the end, a recommendation on which of the three investments would be preferred.

- Activity 2 will be carried out as part of the subject "Advanced Techniques for Financial Simulation". In this activity we will look at different tools and techniques for analyzing financial statements in order to help us make decisions about the company seen in the previous activity (activity 1). Among other things, we will analyze its profitability, liquidity, solvency and efficiency.

- Activity 3 will be carried out as part of the subject "Advanced Techniques for Financial Simulation". In this activity, scenarios will be used to forecast the different results of the model of activity 1 , using a spreadsheet. The variable cells of a scenario are composed of one or more changeable cells and one or more result cells, so that different results are obtained for each change in each of the changeable cells.

As for the evaluation of the activities, it will be carried out both from the reports submitted by the students and from a common sharing in a type of debate in which the students will have to comment on the results obtained to the rest of their classmates.

\footnotetext{
${ }^{1}$ IBEX-35 is the main stock market index of the Spanish stock market and tries to measure the behaviour of the quotations of all the companies with more liquidity in the Madrid Stock Exchange. The IBEX-35 groups the 35 stocks with the highest capitalization, trading and frequency of quotation.
} 


\subsection{Preliminary analysis of the results related to labour market perspective}

As the PBL model is still under development, a preliminary survey addressed to the students has been carried to know their preferences about the PBL methodology. The average age of the students' sample is 25,4 years old in a range from $21-30$ years old. With regards to the gender, $60 \%$ of the students are men and $40 \%$ women.

As the PBL model is developed in the last course, students are relatively near to start working and integrate the labor market, therefore one of the most important aspects that was addressed in the survey was related to the fact that: (i) PBL has allowed students to make decisions in a real situation and (ii) PBL has allowed students to analyze situations similar to those that the ones that they will find in their professional life.

Based on this, Figure 1 shows that all the students support that PBL methodology allows to study and manage situations similar to the reality.

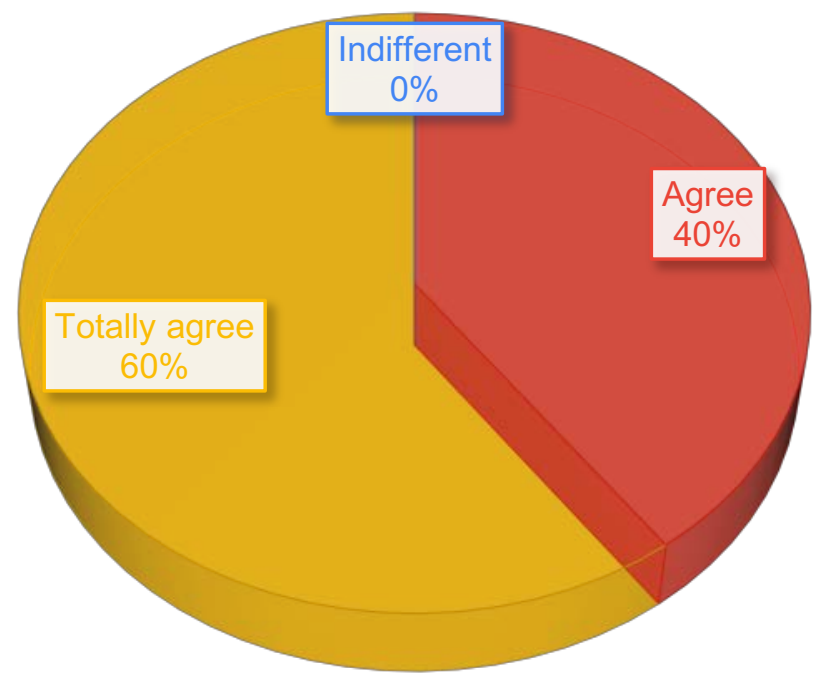

Figure 1. PBL improves the management of similar real situations.

Figure 2 shows that most of the students also support the fact that PBL approach is an appropriate methodology to improve the learning about similar situations that students will have to deal with in their professional life in the near future.

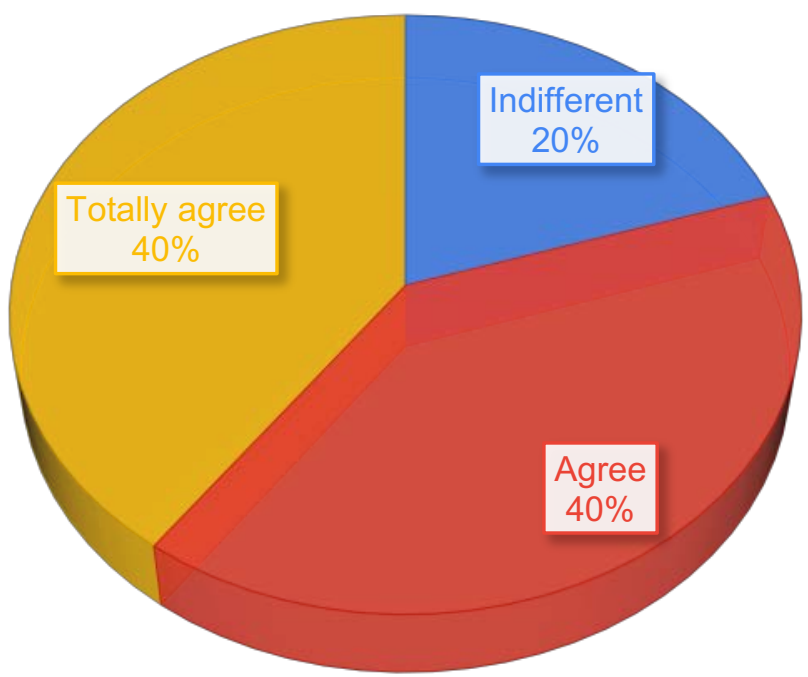

Figure 2. PBL improves the learning of similar situations as in professional life. 


\section{CONCLUSIONS}

Currently, in most of the degrees, the subjects are taught independently, without relating and coordinating the contents with those of other subjects that have been taught previously and without any transversality, focusing only on the program established for each subject. This makes students see more difficult the practical application of everything learned and relate it to the contents of other subjects.

Therefore, in order to try to mitigate this problem, through the PBL model proposed students can link and relate the different contents learnt in different subjects in a way that allows them to deepen their learning and also motivates them to see a practical application of the knowledge acquired in the different subjects.

This will also improve the coordination between the subjects of the degree in Business Administration and Management, allowing at the same time, to favour the students' learning through the cohesion and interrelation between the contents taught in different subjects.

Although the implementation of the project has not been completed yet, the results obtained in the activities that have already been carried seems to lead that the implementation of the project will be successful and that it will bring a series of benefits both to the students such as the improvement of improving students' skills to deal with real problems related to the labour market and to the coordination of the degree itself. With regards to the students' perception about the PBL methodology, a preliminary survey has been launched and the results show that a high percentage (around $80 \%$ of the students) support that PBL improves the learning of similar situations than the ones that happened in real professional life.

However, it should be taken into account that, in this case, the number of students in the subjects is quite small, with only 7 students. Therefore, the monitoring and tutoring of the activities can be carried out in a much more detailed way, which can be considered a limitation in the case of application in much larger groups. In addition, in the current context of the COVID-19 pandemic, the teaching of the subjects is being developed on-line, which entails a limitation when we talk about student-teacher interaction and even among the students themselves.

\section{ACKNOWLEDGEMENTS}

This article has been supported by Universitat Politècnica de València, particularly by the Vice-rectorate for Digital Resources and Documentation (Vicerrectorado de Recursos Digitales y Documentación) and Vice-Rectorate for Studies, Quality and Accreditation (Vicerrectorado de Estudios, Calidad y Acreditación) under the Call for Learning + Teaching (Convocatoria A+D2019: Aprendizaje + Docencia. Proyectos de Innovación y Mejora Educativa) and Project Code: A157. The authors would like to acknowledge the support of the Institute of Educational Sciences (Instituto de Ciencias de la Educación), the Evaluation and Monitoring Commission for Educational Innovation and Improvement Projects (Comisión de Evaluación y Seguimiento de Proyectos de Innovación y Mejora Educativa (CESPIME) and Escuela Politécnica Superior de Alcoy.

\section{REFERENCES}

[1] T. Markham, Project based learning; Design Coaching Guide. California: Wilsted \& Publishing Service, 2012.

[2] W. Sumarni, 2015). "The strengths and weaknesses of the implementation of project based learning: A review" Int J Sci Res, vol. 4, no. 3, pp. 478-484, 2015.

[3] N. Jalinus, R.A. Nabawi, A. Mardin, "The seven steps of project based learning model to enhance productive competences of vocational students", International Conference on Technology and Vocational Teachers (ICTVT 2017), pp. 251 pp.256, Atlantis Press, 2017.

[4] M.M. Grant, "Getting a grip on PBL: Theory, cases and recommendations", Meridian: A Middle School Computer Technologies Journal A Service Of NC State University, Raleigh, vol. 5, no. 1, 2002.

[5] J. Linares-Pellicer, J. Orta-López, J. Salavert-Torres, M.J. Segura Flor, J.A. Silvestre Cerdà, R. Sanchis, "Towards Inter-Subject Project-Based Learning in Programming-Related Courses at Computer Science Studies", EDULEARN Proceedings, pp. 3973 - 3978, 2020. 
[6] J. Esparza Peidro, E.J. Golf Laville, J.J Izquierdo-Doménech, J.V. Tomas Miquel, R. Sanchis, "Definition of Project-Based Learning Models in the Computer Engineering Degree", EDULEARN Proceedings, pp. 3966 - 3972, 2020.

[7] M. Pérez-Sánchez, M. Díaz-Madroñero Boluda, J. Mula, R. Sanchis, "The Sustainable Development Goals (SDGs) Applied to Higher Education. A Project Based Learning Proposal Integrated with the SDGs in Bachelor Degrees at the Campus Alcoy (UPV)", EDULEARN Proceedings, pp. 3997 - 4005, 2020.

[8] M. Pérez-Sánchez, R. Sanchis, "Sustainable Development Goals Integrated in Project-Based Learning in the Mechanical Engineering Degree", Proceedings of INTED2021, pp. 5965 - 7480 7487, 2021.

[9] D. Garcia-Garcia, N. Montanes, L. Quiles-Carrillo, J. Ivorra-Martinez, R. Sanchis, "Implementation of the Project Based Learning Methodology in the "Materials. Design and Restyling" Subject", Proceedings of INTED2021, pp. 9883-9891, 2021.

[10] R. Balart, N. Montanes, L. Quiles-Carrillo, S. Jordá-Gisbert, H.C. Sanchis-Gomis, Sanchis, R., "Model Design and Calculation with Polymeric and Composite Materials through Project-Based Learning", EDULEARN Proceedings, pp. 3979 - 3986, 2020.

[11] C. Carbonell, S.C. Cardona, I. Domínguez, V. Fombuena, M.F. López-Pérez, J. Lora, R. Sanchis, "Project-Based Learning as a Coordination Methodology between Subjects in a Chemical Engineering Degree", Proceedings of INTED2021, pp. 5965 - 5974, 2021.

[12] S.C. Cardona, M.F. López-Pérez, J. Lora, "Aprendizaje basado en problemas en Ingeniería Química como metodología de coordinación vertical/horizontal entre asignaturas", IV Congreso de Innovación Docente en Ingeniería Química (CIDIQ), Santander. 2018.

[13] M.F. López-Pérez, S.C. Cardona, J. Lora, J., A. Abad, J.I. Torregrosa, "Resultados del Proyecto de Innovación y Mejora Educativa. Utilización de MATLAB como estrategia didáctica y de coordinación horizontal y vertical entre asignaturas del Grado de Ingeniería Química", Congreso IN-Red. 2015. http://inred.blogs.upv.es/

[14] R. Sanchis, J. Mula, B. Cantó Colomina, D. Garcia-Sanoguera, J.I. Torregrosa López, “Diseño de la Incorporación del Aprendizaje Basado en Proyectos en las Titulaciones de Grado del Campus de Alcoy de la Universitat Politècnica de València", VI Congreso Nacional de Innovación Educativa y Docencia en Red, Editorial Universitat Politècnica de València, 2020. 